African J. Biol. Sci., 17 (1): 51-61 (2021)

ISSN 1687-4870

e- ISSN 2314-5501 (online)

www.ajbs.journals.ekb.eg

E.mail: aasdjournal@yahoo.com

A study on the effect of wheatgrass on nutritional status and some blood parameters in rats with suppressed immune system

Ekbal M. Saleh*, El Sayeda G. EI Sahar and Rahma S. Elewa

Department of Home Economics-faculty of specific education -Ain-Shams University

*dr.ekbal.mahmoud@sedu.asu.edu.eg

Received: Dec. 28, 2020; Accepted: Feb. 27, 2021; Available online: March 2, 2021

\begin{abstract}
This research was conducted with the aim of evaluating the effect of wheatgrass, which contains chlorophyll and a high percentage of antioxidants such as Vitamin $\mathrm{C}$ and selenium in addition to some minerals such as calcium, iron, and magnesium on the biological efficiency and the immune system in white rats. In the present study, 40 rats were divided into 8 groups, each of 5 rats, and it was divided into two experiments I and II with each trial four groups. In Experiment I, 5 rats were fed the basic meal and were used as a negative control group. The other 15 rats are divided into 3 sub-groups (1,2 and 3$)$ each fed on the main meal plus wheatgrass at rates of 100,150, and $200 \mathrm{mg}$, respectively, and then a method of suppressing the immune system was performed at the end of the trial period. In experiment II, animals were immune suppressed by stress treatment as done in experiment I then divided into 4 groups ( 5 rats each). The first group was served as positive control [Co. (+) ] and fed basal diet only, while the other three groups (4, 5 and 6 ) were served as experimental groups and were fed basal diet and wheatgrass (100, 150 and 200mg).

All groups recorded stability in weight at the beginning and at the end of the experiment and in their acquired increase in their weight gained, food efficiency, intake of food as compared to the control negative group, while groups 4, 5 and 6 had the lowest average rate of food intake compared to the positive control. All groups were found to have no change in the relative weight of their spleen and liver. All the experimental groups recorded no change in the percentage of hemoglobin, red blood cells and hematocrit compared to the control group. Also, they showed a decrease in the MCV rate and $\mathrm{MCH}$ compared to the control groups. All groups recorded no change in the rate of $\mathrm{MCHC}$ and an increase in the rate of RDW\% compared to the control.

Groups 1, 2 and 3 showed a significant decrease in urea and uric acid compared to the control group. While groups 4, 5 and 6 showed a significant increase in urea compared to the control group. All the experimental groups showed an increase in the level of creatinine compared to the control group.
\end{abstract}

Keywords: wheatgrass, immune system, food intake, organ weight, Hemoglobin.

\section{INTRODUCTION}

Immunity is defined as the body's ability to recognize and eliminate foreign materials. Hence the immune system, means the body's natural defense system against foreign materials which penetrate the skin or mucous membranes. Accordingly the immune system enables the body to counter attack certain diseases precursors. The immune system regulates itself by means of the so-called helper suppressor cells and soluble products. It is also in close communication with other systems in the body like the neuroendocrine system and is regulated by those systems as well (Reichlin, 1993). It responses to the hormonal and metabolic changes, which accompany stress, suppress its disease-fighting activity. If malnutrition accompanies stress, the 
Ekbal M. Saleh et al.

immune system is forced to work without adequate nutrient support, which impairs its activity (Whitney et al., 1991).

Wheatgrass is the green leaf of 'baby' red berry wheat plant. In tropical climate wheatgrass grows to a height of around 6 inches in just 7 days. Cutting its green leaf at this jointing stage (before the stem begins to form) and drinking its green chlorophyll rich wheatgrass juice is known to have many therapeutic benefits. It is grown from common wheat (Triticum aestivum), a subspecies of the family Phocaea. It is widely grown throughout temperate regions of North America and Europe. Indigenously, wheatgrass has been used as an herbal medicine since ages. Being a non-toxic herb it also evades Food and Drug Administration screening (Das et al., 2016). Wheatgrass is one of the World strongest immune system boosters because it contains vitamins A, B, C, E, I, K, and every mineral known to mankind. Wheatgrass contains B complex vitamins, calcium, phosphorus, magnesium, sodium and potassium in an adjusted proportion (Akram and Aftab, 2015). It is also a very strong protein source containing more than 15 amino acids. It has countless health benefits like reducing high blood pressure, cleanses body toxic.
This study aimed to investigate the effect of wheatgrass nutrition on the efficiency of the immune system $n$ rats.

\section{MATERIALS AND METHODS}

\section{1) Materials:}

\section{1-Animals:-}

40 male albino rats (100-120 g body weight) were used and they were obtained from the National Research Center (NRC) Dokki Giza, Egypt. Animals were clinically healthy and they randomized and housed in stainless steel wire bottom cages (5 rats / cage) and maintained in air conditioned room on a 12 h light/dark cycle at $22 \pm 2{ }^{\circ} \mathrm{C}$. They were acclimatized under the test conditions for one week before treatments. Rats were fed basal diet with known chemical composition according to Hegsted et al. (1941). The composition of the basal diet ingredients was given in Table (1). The vitamin and salt mixtures were obtained from Modern International Exhibition. Casein was purchased from the Middle East Chemical Company Cairo. Wheatgrass (Tritium aestivum) powder was purchased from Gratitude Company Cairo and its nutrient composition is shown in Table (2).

Table (1): Composition of the Basal Diet.

\begin{tabular}{|c|c|}
\hline Ingredients & Weight $(\mathbf{\%})$ \\
\hline Casein & 15 \\
\hline Corn oil & 10 \\
\hline Cellulose & 5 \\
\hline Vit. Mixture & 1 \\
\hline Salt mixture & 4 \\
\hline Corn starch & $65 \%$ \\
\hline Total & $\mathbf{1 0 0}$ \\
\hline
\end{tabular}

Table (2): Nutrient composition of wheatgrass powder.

\begin{tabular}{|l|l|l|}
\hline \multicolumn{1}{|c|}{ Nutrient composition } & \multicolumn{1}{c|}{ Per $2 \mathrm{~g}$} & \multicolumn{1}{|c|}{ Per 100g } \\
\hline Moisture $(\mathrm{g})$ & 0.13 & 6.30 \\
\hline Protein $(\mathrm{g})$ & 0.50 & 25.00 \\
\hline Fat $(\mathrm{g})$ & 0.02 & 0.90 \\
\hline Carbohydrates $(\mathrm{g})$ & 0.67 & 33.00 \\
\hline Mineral Ash $(\mathrm{g})$ & 0.10 & 4.80 \\
\hline Fiber $(\mathrm{g})$ & 0.6 & 30.00 \\
\hline Vitamin C $(\mathrm{g})$ & 1.26 & 63.00 \\
\hline Calcium $(\mathrm{g})$ & 1.48 & 73.80 \\
\hline
\end{tabular}




\section{A study on the effect of wheatgrass on nutritional status and some blood parameters in rats with suppressed immune system}

\begin{tabular}{|l|l|l|}
\hline Iron $(\mathrm{g})$ & 1.04 & 52.00 \\
\hline
\end{tabular}

During the feeding experiments, animals were daily inspected and food intake was recorded, while body weights were recorded twice a week. The feeding experiment lasted for 6 weeks.

\section{2-Experimental design:}

Experimental diet and water were offered ad labium all over the experimental period. 40 rats were divided into 8 groups (5 rats each), the groups were used in two main experiments.

Experiment I: It included 4groups that were classified as follows:

The first group: was served as negative control [Co (-)] and fed basal diet.

The other three groups (1, 2 and 3$)$ were fed basal diet supplemented with wheatgrass at 100, 150 and $200 \mathrm{mg}$, respectively. At the end of the feeding period (6 weeks), the stress was carried out (for immune suppression) then blood samples were immediately taken for analysis of hematological and immunological parameters.

Experiment II: 20 rats were immune suppressed by stress treatment as done in experiment $I$ then divided into 4 groups ( 5 rats each). The first group was served as positive control [Co. (+) ] and fed basal diet only, while the other three groups $(4,5$ and 6) were served as experimental groups and were fed basal diet and wheatgrass at 100,150 and $200 \mathrm{mg}$, respectively.

\section{Diet design:}

Rats in experimental I (groups 1, 2 and 3) fed on the basic meal + wheatgrass (WG) in the following proportions:

- G1: fed daily orally basic food $+1 \mathrm{ml} /$ rat (100 mg WG/42 ml distilled water).

- G2: fed daily orally basic food+ $1 \mathrm{ml} /$ rat (150 mg WG / $42 \mathrm{ml}$ distilled water).
- G3: fed daily orally basic food $+1 \mathrm{ml} /$ rat (200mg WG/42 ml distilled water).

Then the immunosuppressive process takes place on them by individual treatment of each rat separately where each rat is placed in a glass tube with the same size of rat to be unable to move and closed on both sides with openings for breathing and turning on the back in a dark place at a temperature of $4-5{ }^{\circ} \mathrm{C}$ for 3-4 hours. At the end of the trial period, analyzes were performed (Riley, 1981).

Rats in experimental II with a defect in their immune system from the first day after the initialization period were divided into 3 sub-groups; each group includes 5 rats and fed on the basic meal + wheat grass at the following rates:

- G4: fed basic daily orally food $+1 \mathrm{ml} /$ rat (100 mg / $42 \mathrm{ml}$ distilled water).

- G5: fed daily orally basic food $+1 \mathrm{ml} /$ rat (150 mg / $42 \mathrm{ml}$ distilled water).

- G5: fed daily orally basic food $+1 \mathrm{ml} /$ rat (200mg / $42 \mathrm{ml}$ distilled water).

\section{Determination of food efficiency ratio:}

Food efficiency ratio (FER) was measured according to Chapman et al. (1959): FER= Gain body weight (g)/ food consumed (g) x 10

\section{Blood analysis: \\ Hemoglobin concentration:}

Hemoglobin concentration (g/dI) was determined by colorimetric method using hemoglobin kits. The kits were obtained from the Egyptian American Company for laboratory services. Determination was conducted spectrophotometerically according to the manufacturer.

\section{Packed cell volume (Hematocrit): \\ Blood was withdrawn by} hematocrit capillary tubs, centrifuged for 10 minutes using micro hematocrit centrifuge at 3000r.p.m. Hematocrit (HCT) 
Ekbal M. Saleh et al.

was read and recorded directly as described by Nemi (1986).

\section{Calculation of wintrobe erythrocyte and} platelets indices:

The mean cell volume (MCV), mean cell hemoglobin $(\mathrm{MCH})$, mean cell hemoglobin concentration (MCHC) red cell distribution width (RDW), in addition to blood platelets (PLT), platelets volume (MPV), platelets distribution width (PDW) and PCT were measured by Automated blood cell counting using an electronic blood cell analyzers including those manufactured by Beckman Coulter and System, according to the method of Graig (1998).

\section{Differential of leukocyte:}

Blood films were prepared, air dried and stained by Fleishman's stain [ 0.2 $\mathrm{g}$ of the dye in $100 \mathrm{ml}$ of methanol in a conical flask $200-250 \mathrm{ml}$ and warmed to 50 C FOR $15 \mathrm{~min}$, with occasional shaking then the solution is filtered] for 5-7 min. Slides with blood films were washed in a stream of buffered water until it has acquired a pinkish tinge (up to $2 \mathrm{~min}$ ), and examined according to Dacie and Lewis (1975).

\section{Biochemical analysis:- \\ Determination of serum Urea:}

Serum urea was determined using kits of bio Meraux according to the method of Fawcett and Scott (1960). In this method ammonium ions were produced following enzymatic degradation of urea by urease enzyme. The developed ammonium ions were then reacted with salicylate and hypochlorite in alkaline medium resulting in green color (2.2dicarboxyl indophenol). The produced color was measured calorimetrically at 580 $\mathrm{nm}$.

\section{Determination of serum creatinine: -}

Serum creatinine was measured by the method of Reitman and Frankel (1957) using Bio Meraux reagent kits, after deprotenization, according to the Jaffe reaction (1886). The color developed after the addition of fresh alkaline picrate was measured calorimetrically at $520 \mathrm{~nm}$.

\section{Determination of serum Uric acid:}

Urease-POD enzymatic colorimetric method with 4-amin-antipyrine was used .The assay is based upon the methods of modified tinder peroxidase assay using 3.5- dichloro -2-hydroxybenzenesulfonic acid (BCHB) (Tietz, 1990) .

Serum uric acid concentration $(\mathrm{mg} / \mathrm{ld}$. $)=\mathrm{A}$ specimen/A standard X 6

Concentration of uric acid in urine $=\mathrm{A}$ specimen/A standard X 6 X10

\section{Statistical analysis procedure:-}

The significance of the main effects was determined by analysis of variance (ANOVA), average stander deviation, stander error Duncan. The significance of various treatments was evaluated by Duncan,s multiple range test $(p>0.05)$. All analysis were made using a software package "Costat" a product of cohort software Berkley, California (Duncan, 1955).

\section{RESULTS AND DISCUSSION Effect of different diets on body weight and food intake:}

It was obvious from data in Table (3) that there were no significant differences between the body weight gain of control negative and positive groups of rats at the end of experimental period (6 weeks). The final gained body weight was increased in treated groups 2, 3 and 4 of rats as compared with their respective (C-) groups. While it was increased in groups 4 and 6 and decreased in group 5 as compared with that of $\mathrm{C}+$. The highest increase in the body weight gain was in group (2) $(43.8+22.9 \mathrm{~g})$ and group (4) (57.6 $\pm 13.09 \mathrm{~g})$.

On the other hand, there was a significant increase in food intake of rats in $\mathrm{C}+$ as compared to those in C-. Also, there were no statistically significant differences in food intake for rats in 


\section{A study on the effect of wheatgrass on nutritional status and some blood parameters in rats with suppressed immune system}

groups 2, 3 and 4 as compared with those of C-. However there was a significant decrease in food intake during the experimental period for rats in groups 4,5 and 6 as compared with those of $\mathrm{C}+$ (Table 3). Similar results were obtained by shakya et al. (2016) who reported that treatment with Wheatgrass (WG) and glebe caused a significantly high increase in the average weight gain, daily food and water intake in induced diabetic group of rats. Also, the study of Desai and Tusharbindu (2005) indicated that wheatgrass can diminish fatigue, improve sleep, increase strength, naturally regulate blood pressure and blood sugar and support weight loss (Chauhan, 2014). Also, wheatgrass is beneficial helps to, obesity, constipation, acidity, piles (Hemorrhoids), ulcers, arthritis. Ghoniem et al. (2018) reported that fresh wheat grass juice and its blends decreases the initial body weight and increases final body weight and food intake compared to control group.

Table (3): The effect of different levels of wheatgrass (Tritium aestivum) on final body weight, weight gain, food intake and FER of treated rats for 6 weeks.

\begin{tabular}{|c|c|c|c|c|c|}
\hline \multirow[t]{2}{*}{ Groups } & $\begin{array}{c}\text { Initial } \\
\text { body weight (g) }\end{array}$ & $\begin{array}{l}\text { Final body } \\
\text { weight (g) }\end{array}$ & $\begin{array}{l}\text { Weight } \\
\text { gain }(g)\end{array}$ & $\begin{array}{l}\text { Food intake } \\
\text { (g) }\end{array}$ & FER \\
\hline & Mean \pm SD & Mean \pm SD & Mean \pm SD & Mean \pm SD & Mean \pm SD \\
\hline \multicolumn{6}{|c|}{ Immune suppresses groups at the end of the experiment } \\
\hline $\begin{array}{l}\text { Con (-) } \\
\text { fed basal diet }\end{array}$ & $102.60 \mathrm{a} \pm 9.61$ & $\begin{array}{lll}144.40 & \text { a } & \pm \\
19.40 & & \end{array}$ & $41.80 \mathrm{a} \pm 21.39$ & $20.92 \mathrm{c} \pm 0.02$ & $0.76 \mathrm{a} \pm 0.45$ \\
\hline $\begin{array}{ll}\text { G1: } & \text { fed basal } \\
\text { diet+ } & 100 \mathrm{mg} \text { WG }\end{array}$ & $102.80 \mathrm{a} \pm 9.18$ & $\begin{array}{lll}149.80 & \mathrm{a} & \pm \\
10.50 & & \\
\end{array}$ & $47.00 \mathrm{a} \pm 17.42$ & $20.88 \mathrm{c} \pm 0.00$ & $0.50 \mathrm{a} \pm 0.19$ \\
\hline $\begin{array}{l}\text { G2: fed basal } \\
\text { diet+ } 150 \mathrm{mg} \text { WG }\end{array}$ & $103.80 \mathrm{a} \pm 10.83$ & $\begin{array}{lll}151.60 & \mathrm{a} & \pm \\
16.10 & & \\
\end{array}$ & $47.80 \mathrm{a} \pm 22.91$ & $20.94 \mathrm{c} \pm 0.01$ & $0.56 \mathrm{a} \pm 0.34$ \\
\hline $\begin{array}{l}\text { G3: fed basal } \\
\text { diet+ } 200 \mathrm{mg} \text { WG }\end{array}$ & $102.20 \mathrm{a} \pm 8.70$ & \begin{tabular}{lll|}
146.80 & $\mathrm{a}$ & \pm \\
19.03 & & \\
\end{tabular} & $44.60 \mathrm{a} \pm 24.29$ & $21.06 \mathrm{c} \pm 0.09$ & $0.94 \mathrm{a} \pm 1.17$ \\
\hline \multicolumn{6}{|c|}{ Immune suppresses groups at the beginning of the experiment } \\
\hline $\begin{array}{l}\text { Con }(+) \\
\text { fed basal diet }\end{array}$ & $102.80 \mathrm{a} \pm 8.93$ & \begin{tabular}{lll|}
139.60 & $\mathrm{a}$ & \pm \\
14.91 & & \\
\end{tabular} & $36.80 \mathrm{a} \pm 19.54$ & $24.23 \mathrm{a} \pm 0.02$ & $0.84 \mathrm{a} \pm 0.72$ \\
\hline $\begin{array}{l}\text { G4:fed basal diet+ } \\
\text { 100mg WG }\end{array}$ & $102.20 \mathrm{a} \pm 8.44$ & \begin{tabular}{lll|}
159.80 & $\mathrm{a}$ & \pm \\
7.29 & & \\
\end{tabular} & $57.60 \mathrm{a} \pm 13.09$ & $20.67 \mathrm{~d} \pm 0.37$ & $0.38 \mathrm{a} \pm 0.10$ \\
\hline $\begin{array}{l}\text { G5: fed basal } \\
\text { diet+ } 150 \mathrm{mg} \text { WG }\end{array}$ & $102.80 \mathrm{a} \pm 8.35$ & \begin{tabular}{lll|}
138.20 & $\mathrm{a}$ & \pm \\
12.50 & & \\
\end{tabular} & $35.40 \mathrm{a} \pm 15.66$ & $21.06 \mathrm{c} \pm 0.09$ & $0.70 \mathrm{a} \pm 0.32$ \\
\hline $\begin{array}{lll}\text { G6: fed basal } \\
\text { diet+ }\end{array}$ & $102.80 \mathrm{a} \pm 10.23$ & $\begin{array}{lll}148.80 & \mathrm{a} & \pm \\
25.86 & & \\
\end{array}$ & $46.00 \mathrm{a} \pm 26.09$ & $21.64 \mathrm{~b} \pm 0.02$ & $0.62 \mathrm{a} \pm 0.38$ \\
\hline $\mathbf{F}$ & 0.01 & 0.86 & 0.58 & 348.87 & 0.53 \\
\hline Sig. & 1.00 & 0.54 & 0.77 & 0.00 & 0.80 \\
\hline
\end{tabular}

Least significant differences at $\mathrm{p}<$ _0.05. means with the same letter are insignificantly difference

\section{Effect of different diets on liver and spleen relative weight:}

Data in Table (4) indicated that rats fed on different investigated diets showed no significant difference regarding their liver weights as compared with $\mathrm{C}$ - or $\mathrm{C}+$ groups. Rats in the preventive groups $(\mathrm{G} 1$, 2 and 3) for 6 weeks showed non- significant differences in their spleen weights as compared to the negative control group.

In immune suppressed (Therapeutic groups) animals fed for six weeks on diet supplement with wheatgrass have significant increase in their spleen weights when compared to $\mathrm{C}+$ group. The highest increase was found in group 4. 
Ekbal M. Saleh et al.

Pitchaiah (2016) reported an increase in liver and adrenal gland weights, and decrease in spleen weight in stressed rats. This stress induced changes of organs weights and these were significantly reversed by the wheatgrass juice treatment. Also, treatment with wheatgrass restored oxidative enzymes, and liver glycogen levels, in male Westar rats with Diabetes (Shakya et al., 2016).
Marawaha et al. (2004) reported that liver and spleen sizes are indicators of extra medullary hemopoeisis and thus indirectly indicate the adequacy of blood transfusion. They found a significant difference in liver size within the wheatgrass group and a highly significant difference in spleen size within the wheatgrass and control groups.

Table (4): The effect of different level of wheatgrass on spleen weight and liver weights.

\begin{tabular}{|l|l|l|}
\hline \multirow{2}{*}{ Groups } & Liver & Spleen \\
\cline { 2 - 3 } & Mean \pm SD & Mean \pm SD \\
\hline con(-) & $4.93 \mathrm{a} \pm 0.97$ & $0.55 \mathrm{ab} \pm 0.10$ \\
\hline $\mathrm{G} 1$ & $5.05 \mathrm{a} \pm 2.98$ & $0.52 \mathrm{ab} \pm 0.08$ \\
\hline $\mathrm{G} 2$ & $5.54 \mathrm{a} \pm 0.60$ & $0.51 \mathrm{ab} \pm 0.07$ \\
\hline $\mathrm{G} 3$ & $4.76 \mathrm{a} \pm 0.49$ & $0.59 \mathrm{ab} \pm 0.15$ \\
\hline con(+) & $5.62 \mathrm{a} \pm 1.05$ & $0.46 \mathrm{~b} \pm 0.10$ \\
\hline G4 & $5.75 \mathrm{a} \pm 0.66$ & $0.63 \mathrm{a} \pm 0.15$ \\
\hline G5 & $4.55 \mathrm{a} \pm 0.81$ & $0.51 \mathrm{ab} \pm 0.07$ \\
\hline G6 & $4.77 \mathrm{a} \pm 1.11$ & $0.51 \mathrm{ab} \pm 0.14$ \\
\hline F & 0.59 & 1.21 \\
\hline Sig. & 0.76 & 0.32 \\
\hline \multicolumn{2}{|l}{ Least significant differences at $\mathrm{p}<0.05}$. \\
\hline
\end{tabular}

means with the same letter are insignificantly difference

Hematological analysis:

The effect of different diets on RBC,S count, Hb concentration and hematocrit:
There was no significant difference between groups in RBCs, $\mathrm{HB}$ and hematocrit (Table 5).

Table (5): The effect of different level of wheatgrass (Tritium aestivum) on RBC,s , HB concentration and hematocrit.

\begin{tabular}{|l|c|c|c|c|c|c|}
\hline \multirow{2}{*}{ Groups } & $\begin{array}{c}\text { RBC before } \\
\text { treatment }\end{array}$ & $\begin{array}{c}\text { RBC after } \\
\text { treatment }\end{array}$ & $\begin{array}{c}\text { HGB before } \\
\text { treatment }\end{array}$ & $\begin{array}{c}\text { HGB after } \\
\text { treatment }\end{array}$ & $\begin{array}{c}\text { HCT before } \\
\text { treatment }\end{array}$ & $\begin{array}{c}\text { HCT after } \\
\text { Treatment }\end{array}$ \\
\cline { 2 - 7 } & Mean $\pm \mathrm{SD}$ & Mean $\pm \mathrm{SD}$ & Mean $\pm \mathrm{SD}$ & Mean $\pm \mathrm{SD}$ & Mean \pm SD & Mean \pm SD \\
\hline con (-) & & $7.14 \mathrm{a} \pm 0.26$ & & $14.22 \mathrm{a} \pm 0.65$ & & $39.22 \mathrm{a} \pm 2.13$ \\
\hline G1 & & $6.98 \mathrm{a} \pm 0.35$ & & $13.24 \mathrm{a} \pm 0.50$ & & $37.26 \mathrm{a} \pm 1.16$ \\
\hline G2 & & $6.99 \mathrm{a} \pm 0.86$ & & $13.82 \mathrm{a} \pm 1.36$ & & $39.54 \mathrm{a} \pm 4.98$ \\
\hline G3 & & $7.29 \mathrm{a} \pm 0.59$ & & $13.78 \mathrm{a} \pm 0.96$ & & $38.90 \mathrm{a} \pm 2.85$ \\
\hline con(+) & & $7.19 \mathrm{a} \pm 0.49$ & & $13.82 \mathrm{a} \pm 0.76$ & & $40.04 \mathrm{a} \pm 1.79$ \\
\hline G4 & $7.56 \mathrm{a} \pm 0.38$ & $6.93 \mathrm{a} \pm 0.31$ & $14.54 \mathrm{a} \pm 0.50$ & $12.92 \mathrm{a} \pm 0.35$ & $40.72 \mathrm{a} \pm 1.93$ & $36.00 \mathrm{a} \pm 1.15$ \\
\hline G5 & $7.16 \mathrm{a} \pm 0.78$ & $7.34 \mathrm{a} \pm 0.65$ & $13.92 \mathrm{a} \pm 1.29$ & $13.48 \mathrm{a} \pm 1.08$ & $39.14 \mathrm{a} \pm 3.35$ & $37.32 \mathrm{a} \pm 2.86$ \\
\hline G6 & $7.07 \mathrm{a} \pm 0.45$ & $7.52 \mathrm{a} \pm 1.44$ & $14.38 \mathrm{a} \pm 1.22$ & $14.12 \mathrm{a} \pm 1.62$ & $40.16 \mathrm{a} \pm 2.24$ & $40.06 \mathrm{a} \pm 5.33$ \\
\hline F & 1.07 & 0.40 & 0.46 & 0.97 & 0.48 & 1.12 \\
\hline Sig. & 0.37 & 0.89 & 0.64 & 0.47 & 0.63 & 0.37 \\
\hline
\end{tabular}




\section{A study on the effect of wheatgrass on nutritional status and some blood parameters in rats with suppressed immune system}

\section{The effect of different diets on MCV,} MCH, MCHC and RDW:

It was obvious from data in Table (6) that there was no significant difference between groups in, MCHC; however there was significant difference between treated groups in their MCV, MCH, and RDW. In experiment I (Preventive group- animals fed basic diet and wheatgrass) $\mathrm{MCV}$ decreased significantly in blood samples of groups 1,2 and 3 when compared to the negative control at the end of the experiment. In experiment II (immune suppressed group- animals fed basic diet and wheatgrass) MCV decrease significantly in blood samples of groups 4 , 5 and 6 when compared to negative and positive control groups at the end of the experiment.

In experiment $\mathrm{I}, \mathrm{MCH}$ decreased significantly in blood samples of groups 1 ,
2 and 3 when compared to negative control group at the end of the experiment. Also, in experiment II, MCH decreased significantly in blood samples of groups 4 , 5and 6 when compared to the negative and positive control groups at the end of the experiment.

The levels of RDW in animals fed on different levels of wheatgrass were recorded in Table (6). The results represent animals fed on wheatgrass diets for six weeks then put under stress (experiment I) showed that RDW\% were decreased in blood samples of group (1), while increased in groups 2 and 3 when compared to the negative control group. In immune suppressed (Therapeutic groups) treated rats of groups 4,5 and 6 have significant increase in their RDW\% when compared to positive and negative control groups.

Table (6): The effect of different level of wheatgrass (Tritium aestivum) on (MCV), (MCH), (MCHC) and (RDW\%).

\begin{tabular}{|c|c|c|c|c|c|c|c|c|}
\hline Groups & $\begin{array}{l}\text { MCV } \\
\text { before } \\
\text { treatment }\end{array}$ & $\begin{array}{l}\text { MCV } \\
\text { after } \\
\text { treatment }\end{array}$ & $\begin{array}{l}\text { MCH } \\
\text { before } \\
\text { treatment }\end{array}$ & $\begin{array}{l}\text { MCH } \\
\text { after } \\
\text { treatment }\end{array}$ & $\begin{array}{l}\text { MCHC } \\
\text { before } \\
\text { treatment }\end{array}$ & $\begin{array}{l}\text { MCHC } \\
\text { after } \\
\text { treatment }\end{array}$ & $\begin{array}{l}\text { RDW\% } \\
\text { before } \\
\text { treatment }\end{array}$ & $\begin{array}{l}\text { RDW\% } \\
\text { after } \\
\text { treatment }\end{array}$ \\
\hline & $\begin{array}{l}\text { Mean } \pm \\
\text { SD }\end{array}$ & $\begin{array}{l}\text { Mean } \pm \\
\text { SD }\end{array}$ & $\begin{array}{l}\text { Mean } \pm \\
\text { SD }\end{array}$ & $\begin{array}{l}\text { Mean } \pm \\
\text { SD }\end{array}$ & $\begin{array}{l}\text { Mean } \pm \\
\text { SD }\end{array}$ & $\begin{array}{ll}\text { Mean } & \pm \\
\text { SD } & \\
\end{array}$ & $\begin{array}{l}\text { Mean } \pm \\
\text { SD }\end{array}$ & $\begin{array}{l}\text { Mean } \pm \\
\text { SD }\end{array}$ \\
\hline $\begin{array}{l}\operatorname{con}(-) \\
\text { (a) }\end{array}$ & & $\begin{array}{l}55.76 \mathrm{a} \pm \\
1.87 \\
\end{array}$ & & $\begin{array}{l}19.80 \mathrm{a} \pm \\
0.55\end{array}$ & & $\begin{array}{l}35.52 \text { a } \pm \\
0.28 \\
\end{array}$ & & $\begin{array}{l}21.68 \mathrm{~b} \pm \\
1.75\end{array}$ \\
\hline G1 & & $\begin{array}{l}53.40 \mathrm{ab} \\
\pm 1.53\end{array}$ & & $\begin{array}{l}18.98 \mathrm{ab} \pm \\
0.44\end{array}$ & & $\begin{array}{l}35.54 \mathrm{a} \pm \\
0.31\end{array}$ & & $\begin{array}{l}21.92 \mathrm{~b} \pm \\
0.84\end{array}$ \\
\hline G2 & & $\begin{array}{l}53.86 \text { ab } \\
\pm 2.86\end{array}$ & & $\begin{array}{l}19.40 \mathrm{ab} \pm \\
0.91\end{array}$ & & $\begin{array}{l}35.66 \text { a } \pm \\
1.07\end{array}$ & & $\begin{array}{l}23.02 \mathrm{~b} \pm \\
0.48\end{array}$ \\
\hline G3 & & $\begin{array}{l}53.44 \text { ab } \\
\pm 2.79\end{array}$ & & $\begin{array}{l}18.98 \mathrm{ab} \pm \\
0.86\end{array}$ & & $\begin{array}{l}35.54 \text { a } \pm \\
0.67\end{array}$ & & $\begin{array}{l}22.56 \mathrm{~b} \pm \\
1.29\end{array}$ \\
\hline $\operatorname{con}(+)$ & & $\begin{array}{l}54.92 \mathrm{a} \pm \\
3.05\end{array}$ & & $\begin{array}{l}19.38 \mathrm{ab} \pm \\
1.02\end{array}$ & & $\begin{array}{l}35.30 \text { a } \pm \\
0.64\end{array}$ & & $\begin{array}{l}22.04 \mathrm{~b} \pm \\
0.73\end{array}$ \\
\hline G4 & $\begin{array}{l}53.88 \mathrm{a} \pm \\
1.95\end{array}$ & $\begin{array}{l}53.26 \text { ab } \\
\pm 2.20\end{array}$ & $\begin{array}{l}19.18 \mathrm{a} \pm \\
0.76\end{array}$ & $\begin{array}{l}19.10 \mathrm{ab} \pm \\
0.60\end{array}$ & $\begin{array}{l}35.56 \mathrm{a} \pm \\
1.19\end{array}$ & $\begin{array}{l}35.88 \text { a } \pm \\
0.36\end{array}$ & $\begin{array}{l}19.16 \mathrm{a} \pm \\
1.16\end{array}$ & $\begin{array}{l}23.38 \text { ab } \\
\pm 0.13\end{array}$ \\
\hline G5 & $\begin{array}{l}54.82 \mathrm{a} \pm \\
2.51 \\
\end{array}$ & $\begin{array}{l}50.96 \mathrm{~b} \pm \\
1.48\end{array}$ & $\begin{array}{l}19.46 \mathrm{a} \pm \\
0.82\end{array}$ & $\begin{array}{lll}18.38 & b \quad \pm \\
0.50 & & \end{array}$ & $\begin{array}{l}35.54 \mathrm{a} \pm \\
0.60\end{array}$ & $\begin{array}{l}36.06 \text { a } \pm \\
0.29\end{array}$ & $\begin{array}{l}19.82 \mathrm{a} \pm \\
0.81\end{array}$ & $\begin{array}{l}23.40 \mathrm{ab} \\
\pm 1.77\end{array}$ \\
\hline G6 & $\begin{array}{l}55.16 \mathrm{a} \pm \\
1.79 \\
\end{array}$ & $\begin{array}{l}53.74 \text { ab } \\
\pm 3.19 \\
\end{array}$ & $\begin{array}{l}19.52 \mathrm{a} \pm \\
0.58 \\
\end{array}$ & $\begin{array}{l}19.00 \mathrm{ab} \pm \\
1.50\end{array}$ & $\begin{array}{l}35.30 \mathrm{a} \pm \\
0.97\end{array}$ & $\begin{array}{l}35.36 \text { a } \pm \\
0.71\end{array}$ & $\begin{array}{l}20.60 \mathrm{a} \pm \\
1.27\end{array}$ & $\begin{array}{l}25.10 \mathrm{a} \pm \\
2.32 \\
\end{array}$ \\
\hline $\mathbf{F}$ & 0.50 & 1.61 & 0.31 & 1.16 & 0.12 & 0.89 & 2.15 & 3.35 \\
\hline Sig. & 0.62 & 0.17 & 0.74 & 0.35 & 0.89 & 0.53 & 0.16 & 0.01 \\
\hline
\end{tabular}

Least significant differences at $\mathrm{p}<\_0.05$. means with the same letter are insignificantly difference 
Ekbal M. Saleh et al.

Radhey et al. (2007) reported that wheatgrass juice therapy decreased the total volume of blood transfused and increased the intervals between blood transfusions of the entire study cohort and the beneficial effects of this therapy have been attributed to its rich nutritional content that includes antioxidant vitamins $(\mathrm{C} \& \mathrm{E})$ and bioflavonoids. They also referred the effects of the wheatgrass juice therapy to the action of natural antioxidants of red blood cell (RBC).

The WG has up to $70 \%$ of chlorophyll (known as green Blood) a blood builder as both chlorophyll and human Hemoglobin $(\mathrm{Hb})$ share an identical atomic structure in Having tetra pyrrole rings with only major difference that Magnesium in central metal atom in chlorophyll instead of Iron as in hemoglobin. Magnesium is beneficial for about 30 enzymes. Chlorophyll also contains superoxide dismutase that decomposes superoxide radicals in the Blood (Devi et al., 2015). Also, Khan et al. (2015) found that WG improved hematological parameters (RBC, TLC, DLC and Platelet count).

Shah et al. (2011) reported that after 3 weeks of intervention with fresh WGJ (150 ml/day), a significant elevation of hemoglobin, RBCs count, lymphocytes and platelets count was elicited, while there was a reduction in the total leukocytes count compared to the results before the intervention of the juice. Similar results were given by Borisenko and Sofonova (1965) who found a significant increase in hemoglobin, RBCs count, total and differential WBC's and platelets count in thrombocytopenic rats supplemented with fresh juice of wheatgrass. The beneficial effect of WGJ to increase RBCs count may be due to its induction of hemopoietic effect. Jigisha et al. (2015) found that adding WG to leukemia patients diets, can significantly reduce the severity of nausea, vomiting, bone pain, fever, skin rash, hair loss, mouth ulceration, anorexia and loss of weight, in addition improved hemoglobin, red blood cell count and platelet.

Severe neutropenia $(<0.5 \mathrm{~K} / \mathrm{uL})$ is the main risk factor for infections Therefore, it is important to consider therapies that may provide support for the immune system and specifically for WBC counts during chemotherapy.

The effect of different diets on kidney function, urea, uric acid and Creatinine:

Table (7) showed the changes on levels of urea, uric acid and Creatinine after treatment the different investigated rat groups with wheatgrass for 6 weeks. In experiment I (animals fed basic diet and wheatgrass in Preventive group) the urea level decreased significantly in rats of group 1, while increased in groups 2 and 3 when compared to the negative control at the end of the experiment.

In experiment II (immune suppressed rats fed basic diet and wheatgrass) the urea level increased significantly in groups 4,5 and 6 when compared to the negative and positive control groups at the end of the experiment.

In experiment I, the level of uric acid decreased significantly in rats of groups 1, 2 and 3 when compared to the negative control at the end of the experiment. While, in experiment II the uric acid increased significantly in rats of groups 4, 5 and 6 when compared to both negative and positive control groups at the end of the experiment.

The present results also showed that the level of creatinine had no change in group 1, while increased in rats of groups 2 and 3 after six weeks of treatment when compared to the negative control at the end of the experiment. However the level of creatinine was increased in groups 4, 5 and 6 after six weeks when compared to the negative and positive e control groups at the end of the experiment. 


\section{A study on the effect of wheatgrass on nutritional status and some blood parameters in rats with suppressed immune system}

It was noticed that the significantly improvement in uric acid and urea response were detected in animals of experiment I (Preventive group) more butter than that in group of experiment II(treatment group). This result agreed with the finding of Shakib et al. (2017) about beneficial effect of wheatgrass juice on some biochemical parameters in Type 2 diabetic subjects with reduced lymphocytes count found that low level of uric acid and urea and high percentage of Creatinine in patients who ate wheatgrass . Also, this result was confirmed by many studies which reporting that WG juice possess a beneficial effect on kidney malfunction and inflammation (Shaikh and Quazi, 2012).

Table (7): The effect of different level of wheatgrass (Tritium aestivum) on, urea, uric acid and creatinine.

\begin{tabular}{|l|l|l|l|l|l|l|}
\hline & \multicolumn{1}{|c|}{$\begin{array}{c}\text { Urea } \\
\text { before } \\
\text { treatment }\end{array}$} & $\begin{array}{c}\text { Urea } \\
\text { after } \\
\text { treatment }\end{array}$ & $\begin{array}{c}\text { Uric acid } \\
\text { before } \\
\text { treatment }\end{array}$ & $\begin{array}{c}\text { Uric acid } \\
\text { after } \\
\text { treatment }\end{array}$ & $\begin{array}{c}\text { Creatinine } \\
\text { before } \\
\text { treatment }\end{array}$ & $\begin{array}{c}\text { Creatinine } \\
\text { after } \\
\text { treatment }\end{array}$ \\
\cline { 2 - 7 } & Mean $\pm \mathrm{SD}$ & Mean $\pm \mathrm{SD}$ & Mean $\pm \mathrm{SD}$ & Mean $\pm \mathrm{SD}$ & Mean $\pm \mathrm{SD}$ & Mean $\pm \mathrm{SD}$ \\
\hline G1 $(-)$ & & $39.60 \mathrm{ab} \pm 9.74$ & & $3.14 \mathrm{a} \pm 0.38$ & & $0.63 \mathrm{c} \pm 0.07$ \\
\hline G2 & & $36.98 \mathrm{~b} \pm 5.13$ & & $2.38 \mathrm{~b} \pm 0.24$ & & $0.63 \mathrm{c} \pm 0.05$ \\
\hline G3 & & $40.34 \mathrm{ab} \pm 3.00$ & & $2.46 \mathrm{~b} \pm 0.11$ & & $0.75 \mathrm{ab} \pm 0.06$ \\
\hline con(+) & & $41.34 \mathrm{ab} \pm 7.56$ & & $2.50 \mathrm{~b} \pm 0.27$ & & $0.66 \mathrm{bc} \pm 0.05$ \\
\hline G4 & $55.60 \mathrm{a} \pm 9.66$ & $42.66 \mathrm{ab} \pm 8.07$ & $1.88 \mathrm{a} \pm 0.84$ & $3.52 \mathrm{a} \pm 0.68$ & $0.68 \mathrm{a} \pm 0.08$ & $0.75 \mathrm{ab} \pm 0.05$ \\
\hline G5 & $66.80 \mathrm{a} \pm 18.90$ & $47.52 \mathrm{a} \pm 7.99$ & $1.62 \mathrm{a} \pm 0.56$ & $3.40 \mathrm{a} \pm 0.28$ & $0.71 \mathrm{a} \pm 0.12$ & $0.77 \mathrm{a} \pm 0.12$ \\
\hline G6 & $61.80 \mathrm{a} \pm 17.75$ & $45.86 \mathrm{ab} \pm 5.52$ & $1.90 \mathrm{a} \pm 0.63$ & $3.66 \mathrm{a} \pm 0.86$ & $0.73 \mathrm{a} \pm 0.18$ & $0.78 \mathrm{a} \pm 0.07$ \\
\hline F & 0.62 & 1.25 & 0.25 & 6.32 & 0.18 & 5.20 \\
\hline Sig. & 0.56 & 0.31 & 0.78 & 0.00 & 0.84 & 0.00 \\
\hline
\end{tabular}

Least significant differences at $\mathrm{p}<\_0.05$.

means with the same letter are insignificantly difference

\section{Conclusion}

The results of this study summarized that wheatgrass has an effect on maintaining weight, not gaining excess weight, maintaining hemoglobin level in the blood, and reducing the level of urea and uric acid in the blood of rats suppressed immune system.

\section{REFERENCES}

Akram, M. and Aftab, F. (2015). Effect of Cytokinins on In vitro seed Germination and Changes in Chlorophyll and Soluble Protein Contents of Teak (Tectona grandis L.). Biochem. Physiol., 2015; 4:166.

Borisenko, A.N. and Sofonova, A.D. (1965). Hemopoietic effect of $\mathrm{Na}$ chlorophyllin. Vrach Delo, 9:4446.

Dacia, J.V. and Lewis S.M. (1975). Practical Hematology. $5^{\text {th }}$ ed. Churchill Living Stone, 23 Ravel stone Terrace, Edinburgh EH43TL.PP:85-119.

Devi, S.K.; Hariprasath, K.; Nalini, G.R.; Veenaeesh, P. and Ravichandra, S. (2015): Wheat grass Juice-Triticum aestivum Linn a therapeutic tool in pharmaceutical research, an overview. IJJPR. Human, 3(3):112121.

Duncan, D.B. (1955). Multiple ranges and multiple F test Biometrics 11:1-42.

Desai, S. and Tusharbindu, R.(2005). Investigation into the mechanism of action and effects of Triticum 
Ekbal M. Saleh et al.

aestivum (Wheat grass), Ph.D. Thesis, Saurashtra University. Available at http:/ etheses. saurashtrauniversity.edu/id/eprint/1 88.

Fawcett, D.W. and Scott, B. (1960). Bloom and Fawcett textbook of histology $5^{\text {th }} \quad$ Ed Saunders, USA.542-550.

Ghoniem, A.A.; Abou-Raya, M.A.; Abd EL Hameed, A.K. and Elrayes, N.M. (2018). Influence of Using Fresh Wheat Grass Juice and its Blends on Hypercholesterolemic Rats J. Food and Dairy Sci., 3rd Mansoura International Food Congress (MIFC) October: 137145.

Hegested, D.M.; Mills, R.C.; Elvehijem, C.A. and Hart, F.B. (1941). Choline in nutrition of check. J. Biol . Chem., 138:459.

Jigisha, M.S.; Solanki, K.L. and Bhaidpatel, L. (2015). Clinical efficacy evaluation of wheat grass tablets as supportive treatment in leukemia patients. RJPBCS, 6(4):1450.

Khan, N.; Ganeshpurkar, A.; Dubey, N. and Bansal, D. (2015). Immunoprophylactic potential of wheat grass extract on benzene-induced leukaemia: An in vivo study on murine model. Ind. J. Pharmacol., 47(4):394-397.

Marawaha, R.K.; Bansal, D.;Kaur, S. and Trehan, A. (2004). Wheat grass juice reduces transfusion requirement in patients with thalassemia major: a pilot study. Ind. Pediatr., 41:716-720.

Pitchaiah, G. (2016). Evaluation of adoptogenic activity of wheatgrass juice in rodents. J Pharm. Chem. Biol. Sci.; 3(4):499-505.

Riley, M.J. (1981). Stress: physical symptoms; Causes of stress. Eur. J. Immunol., 23:1552-1560.
Reichlin, S. (1993). NeuroendocrineImmune interactions. N. Engl. Med., 329:1246-1253.

Reitman, S. and Frankel, S. (1957). A calorimetric methods for the determination of serum glutamicoxaloacetic and glutamicphyrovate transaminase. A.M.J. Clin. Path.:28-56.

Radhey, S.S.N.; Singh, P.V. and Vijay, K.S. (2007). Wheat grass supplementation decreases oxidative stress in healthy subjects: A comparative study with Spirulina. J. Alternative and Complementary Med., 13(8):789792.

Shakya, G.; Randhi, K.B.; Pajaniradje, S.; Mohankumar, K. and Rajagopalan, R. (2016). Hypoglycaemic role of wheatgrass and its effect on carbohydrate metabolic enzymes in type II diabetic rats Toxicol. and Industrial Health, 32(6): 10261032.DOI: $10.1177 / 0748233714545202$

Shah, K.V.;Thumber, B.L. and Desai,T.R. (2011). Investigation into therapeutic role of Triticum aestivum (Wheat) grass in busulfan induce thrombocytopenia. Int. J. Universal Pharm. and Life Sci., 1 (1): 85-97

Shakib, M.C.; Gabrial, S.G. and Gabrial, N.G. (2017). Beneficial effect of wheatgrass juice on some biochemical parameters in Type 2 diabetic subjects with reduced lymphocytes count. RJPBCS 8(1): 1952.

Shaikh, M.R.N. and Quazi, M. (2012). Hypoglycemic effect of wheatgrass juice in alloxan induced diabetic rats. F.S. J. Pharm. Res., 1 (2): 3940. 


\title{
A study on the effect of wheatgrass on nutritional status and some blood parameters in rats with suppressed immune system
}

\author{
دراسة تأثير عثبة القمح على الحالة الغذايئة وبعض قياسات الدم فى الفئران المثبطة الجهاز المناعى \\ أقبال محمود صالح ، السيدة غندور السيد السحار ، رحمة صابر كمال عليوه

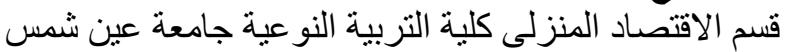

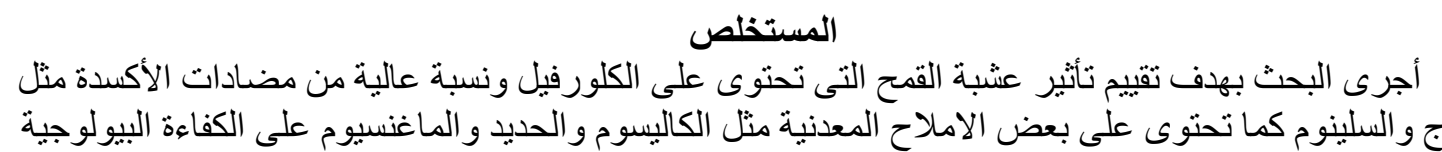

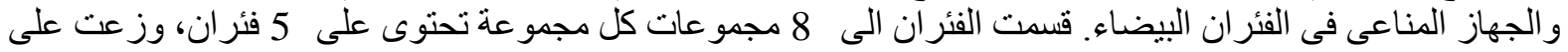

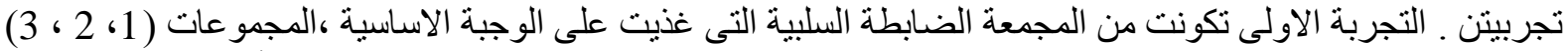

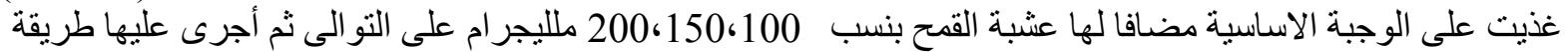

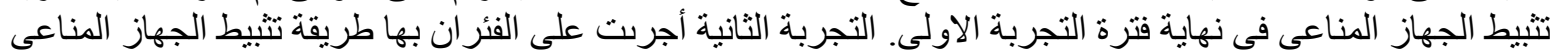

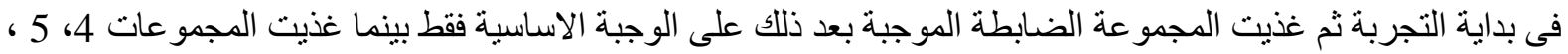

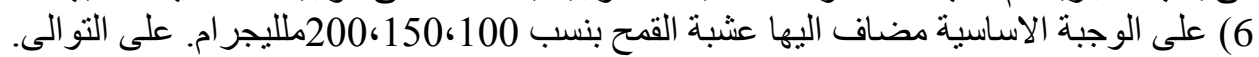

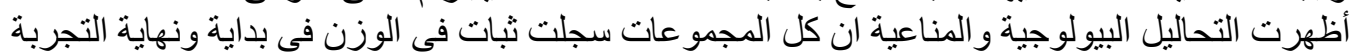

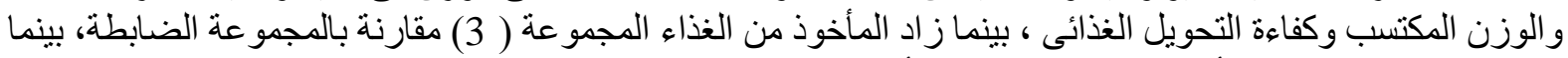

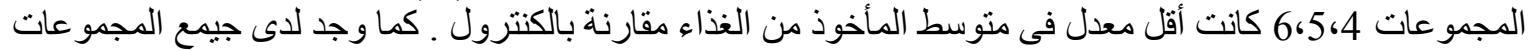

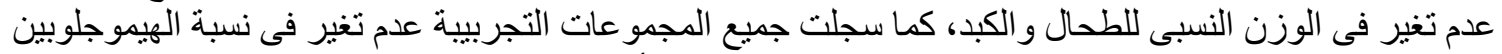

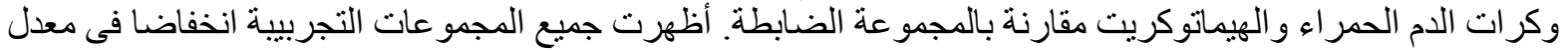

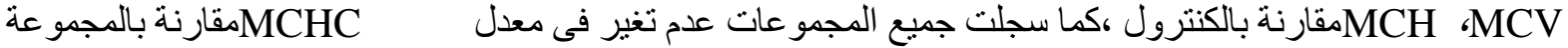

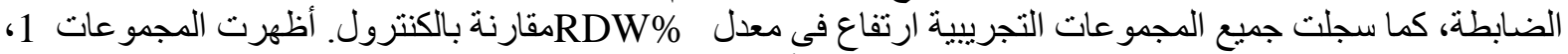

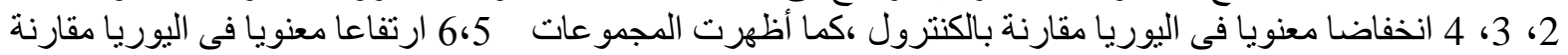

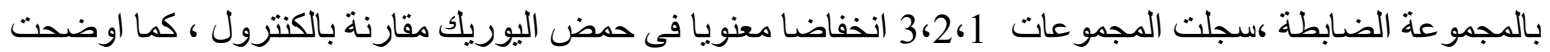

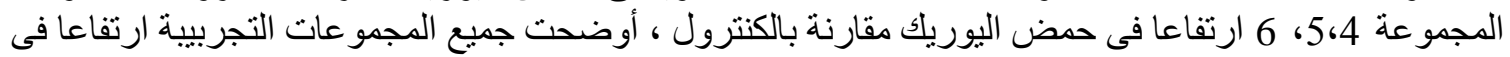
مستوى الكريانين مقارنة بالمجمو عة الضابطة. 